\title{
JOURNAL.RU
}

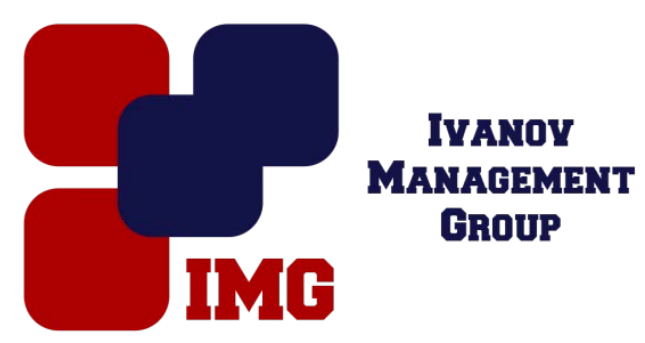

Попружук Ю.С.

Иркутский Государственный Университет Иркутск, Россия

doi: 10.18411/lj-28-02-2017-2-08

idsp 000001:lj-28-02-2017-2-08

\section{Инновационная деятельность в КНР: китайский путь равития}

\section{Аннотация}

В статье рассматриваются вопросы инновационной деятельности Китая последних лет, даются оценка инновационного развития страны и причины, приведшие КНР к достигнутому уровню.

Ключевые слова: Китай; инновации; китайские предприниматели; поддержка государства.

В настоящее время основа устойчивого экономического роста государства зависит от многих факторов: эффективного функционирования политической и партийной системы [1], повышения стандартов качества продукции [7] и хозяйственной культуры [4]. Однако ключевым остается такой фактор, как уровень развития и динамизма инновационной сферы. На первые места в мире выходят компании, которые непрерывно работают над развитием национальных инновационных программ, обеспечивая своим странам уверенный подъем экономического роста. Инновационная ориентированность государственной торговли превосходит сырьевую, так как она менее зависима от колебаний цен на мировых рынках, а следовательно - более устойчива к мировым финансовым потрясениям.

Каков же при этом инновационный потенциал Китая? Десятилетиями множество экспертов по всему миру с сомнением относились к способности КНР на создание уникальных технологий, продолжая рассматривать Поднебесную в качестве имитатора или «Империи подделок». КарлиФиорина, председательница правления и главная управляющая американской компании Hewlett-Packard, еще в 2015 году утверждала, что: «Несмотря на то, что китайцев можно назвать одаренной нацией, инновационная деятельность и предпринимательство не являются их сильными сторонами.» Ведущие экономисты считали китайский социальный строй и образовательную систему слишком контролируемыми и гомогенизированными для того, чтобы поощрять желание ученых и изобретателей 
брать на себя вполне ожидаемые риски.

Но в последнее время ситуация начала кардинально меняться. Инновационные успехи Китая стали одной из самых обсуждаемых тем в западных медиа в течение всего предыдущего года. Уже в октябре 2015-ого в колонке Шумпетера журнала TheEconomist Китай был признан способным на инновационные успехи в определенных областях. Под «определенными» областями имелась в виду возможность КНР создавать инновационные бизнесмодели, быстро адаптируемые к постоянно меняющейся среде. В этой статье впервые на уровне популярных западных изданий был признан ранее постоянно подвергавшийся сомнениям китайский инновационный потенциал. Главы крупнейших мировых компании стали говорить о том, что в ближайшие годы Китай будет способен построить мощнейший технический центр, который во многом превзойдет высокоразвитую американскую Силиконовую долину.

Несомненно, китайское правительство всеми силами старается поднять свое государство на новые высоты технологического развития. Эра, когда КНР считался одним лишь изготовителем дешевых и некачественных подделок, медленно подходит к концу; усиленная работа над инновациями стала важнейшим элементом в государственном плане на будущие годы. Что предшествовало осознанию КПК необходимости развивать национальные инновационные программы?

В конце 70-х годов прошлого века, с приходом к руководству Дэн Сяопина правительству пришлось признать, что экономика Китая отставала по сравнению с западными странами-лидерами, а разрыв в уровнях развития можно было назвать огромным. После подобного столкновения с реальностью нация с тысячами лет богатой истории за плечами, обитавшая до того момента в абсолютной утопии, была повержена в шок. Так для китайских предпринимателей возникла новая цель - заявить всему миру о своих возможностях.

В 2006 г. в Китае была принята долгосрочная программа развития науки и техники. Было заявлено о намерении превратить Китай к 2020 г. в «инновационное общество», а к 2050 г. - в мирового лидера в области науки и технологий.По словам председателя КНР, (XVII съезд КПК), «суть инновационного государства заключается в том, чтобы мощь науки и техники способствовала экономико-социальному развитию и обеспечению национальной безопасности, чтобы синтез базовых научных исследований и изучения передовых технологий существенно усиливал и позволял достичь таких научно-технических результатов, которые были бы существенны для всего мира» [2]. Была поставлена цель уменьшить зависимость КНР от иностранных технологий и превратить предприятия и деловой сектор в центральную движущую силу процесса образования национальной инновационной системы. С тех пор Китай, ранее известный всему миру как имитатор технологий других стран, начал постепенно внедрять собственные инновации и достиг в этом определенных успехов. Каковы причины инновационного рывка КНР вперед?

Одним из мощнейших двигателей китайских инновационных технологий 
явилась хорошо известная государственная поддержка, выраженная не только в развитии образования, технопарков и инфраструктуры, но в предоставлении прямых субсидий государственным предприятиям для инновационных исследований. Инвестиции КНР в НИОКР (как процентная часть годового ВВП) выросли с 0.9\% (2000 г.) до 2.0\% (2015 г.), и ожидается, что вклад возрастет до $2.5 \%$ к 2020 году. Для сравнения, доля Китая в числе мировых НИОКР составляет (по данным 2015 года) 20\%, доля Японии при этом - 9\%, Германии -6\%, опережает КНР только США с 26\%. В 2015 году национальные затраты КНР на научные исследования и эксперименты составили 1.42 триллиона юаней (213.4 миллиона долларов); за этим последовало второе в мире количество опубликованных на научной базе исследовательских работ; инновационный потенциал Китая занял восемнадцатое место в мире.

Одними из основных двигателей инноваций являются университеты, которые в КНР с каждым годом создают все больше совместных с другими странами инновационных моделей обучения [6], проводят международные исследования [5] увеличивают набор студентов. Если в 1998 г. в университетах Китая обучалось 3,4 млн студентов (для сравнения: в США тот же период - 14,5 млн), то в 2012 г. эта цифра составила уже 23,9 млн человек, или на 4 млн больше, чем в США. Что касается ученых степеней, то ожидается, что в ближайшем будущем в Китае число их обладателей будет выше, чем в любой другой стране мира. Тем не менее, китайские университеты, по мнению западных экспертов, вряд ли смогут стать серьезным двигателем инноваций из-за ограничивающего их активность слишком сильного партийного контроля. Однако премьер-министр Китая Ли Кэцян заявил, что Китай будет преодолевать ограничения в своей институциональной системе, чтобы оказывать содействие инновационному развитию в области технологий. Во время встречи с М. Макнут, главным редактором одного из ведущих мировых научных журналов Science, он отметил, что Китай будет углублять свои реформы, а креативность людей станет центром инноваций. По мнению Марции Макнут, первой женщины-редактора со дня основания журнала (1880 г.), сейчас КНР рассматривает науку как неотъемлемую часть своего будущего и будет использовать научную информацию для разрешения мировых проблем.

Правительство страны запустило в действие широкий спектр программ, нацеленных на культивирование научного таланта. Многочисленные фонды, такие, как NationalScienceFundforDistinguishedYoungScholarsили theChangJiangScholarsProgram, спонсируют работу молодых ученых над многообещающими проектами или пытаются привлечь иммигрировавших из Китая ученых обратно в родную страну.

Помимо этого, КНР представляет собой очень быстро развивающийся большой рынок. Это способствует легкому внедрению новых продуктов, а острая необходимость вытеснять конкурентов при этом отсутствует. Компании могут больше рисковать и апробировать новые идеи, т.к. быстрый рост рынка более снисходителен к инновационным неудачам. 
Китай также отличается наличием большого количества недорогих, в сравнении с западными странами, инженеров и ученых. Эта высокопрофессиональная рабочая сила задействована в Китайских и иностранных компаниях и занимается разработкой новейших инновационных технологий, что было бы очень дорого в государствах с рыночной экономикой. Таким образом, у КНР есть возможность выделить значительно больше людей для определенных научных проектов, что остается весомой проблемой среди их зарубежных конкурентов.

Потребность китайского населения в простой продукции, более доступной, чем та, которая предлагается компаниями из развитых стран, также способствует инновациям. В Китае и центральное, и провинциальные правительства могут в короткие сроки реализовывать такие масштабные проекты, как строительство высокоскоростной железной дороги или нового аэропорта, которые, в свою очередь, открывают широкие возможности для инноваций.

Ведущий принцип современного экономического развития КНР - это экономика открытых дверей (см.Дж. Хэй), что соответствует требованиям глобализации мирового сообщества [8] и доктрине «мягкой силы» [13]. В Китае поощряется обмен опытом отечественных компаний с зарубежными, как и всякий другой культурный обмен [9], но в то же время налицо стремление обрести собственный путь развития, который бы учитывал и местные особенности, и специфику регионального развития [3].

Китай заинтересован в создании такого бизнеса, который не только существенно увеличит экспорт, но и создаст более высокооплачиваемые места. Имея более высокую заработную плату, население будет способствовать росту внутреннего потребления и экономическому развитию страны. В целом эксперты отмечают очень высокий потенциал современного Китая в области инноваций, который, по их мнению, в перспективе будет расти.

Стоит отметить, что вся проделанная Китайским правительством работа дала свои результаты. Как уже упоминалось выше, инновационные успехи КНР стали одной из самых обсуждаемых тем в западной прессе в течение всего 2016 года.

На XI Международной Выставке Авиации (ноябрь 2016 г.) был представлен новейший истребитель J-20, а также самый большой в мире самолет-амфибия AG600, сделанный в Китае. Длина AG600 достигает 37 метров, а размах крыла 38,8 метров. Этот самолет размером с Боинг 737 можно использовать для борьбы с лесными пожарами и в спасательных морских операциях. В ноябре в Чэнду был запущен первый поезд на литиевых батареях, который не касается железнодорожных путей. Самый большой и чувствительный радиотелескоп в мире, FAST, диаметр которого составляет 500 метров, был запущен в сентябре прошлого года. Задания FAST включали исследование нейтрального водорода в космосе, наблюдение за пульсарами, а также слежение за космическими объектами и различного рода коммуникации. Новый китайский суперкомпьютер Sunway-TaihuLight, расположенный в Вукси, восточной китайской провинции 
Цзянсу, стал самым быстрым компьютером на Международной Конференции в Германии 20 июня 2016 г. Массивный суперкомпьютер полностью построен из процессоров, разработанных и сделанных в Китае. Машина свергла с трона бывшего чемпиона Tianhe-2, тоже китайскую систему, построенную на базе чипов Intel. TaihuLight способен представить 93 миллиарда вычислений за секунду. Это почти в три раза быстрее его предшественника [10].

Китай вступил в новую эру. Новое поколение предпринимателей, движимых молодостью и богатым потенциалом, полны сил и энергии. Разумеется, далеко не каждому из них удастся преуспеть в инновационной деятельности. Нельзя забывать и том, что идеологическая политика КНР продолжает, по большей части, мешать молодым энтузиастам. Но пока новое поколение предпринимателей не нарушает законы и удовлетворяет желания потребителей, китайское правительство готово приветствовать риски и испытания. Возможно, новая эра, эра инноваций, станет одной из важнейших частей в долгой истории Китая. 


\section{Литература}

1. Баринкова А.В., Кремнёв Е.В. Партийная система КНР в типологическом аспекте: однопартийность или неконкурентная многопартийность? // CredeExperto: транспорт, общество, образование, язык. 2015. № 3. С. 129-142.

2. Березин А.Н. Китай: национальная стратегия инновационного развития / IV Международная студенческая электронная научная конференция «Студенческий научный форум» ГЭлектронный ресурс]. - $2012 . \quad$ - http: https://www.rae.ru/forum2012/11/2380

3. Горчакова Т. Е. Инновационная деятельность КНР (по оценкам западных и китайских экспертов за 2014 г.) / Проблемы Дальнего Востока. - 2015. - №2. - 59-64 с.

4. Кобжицкая О.Г. Духовные основы хозяйственной культуры. Диссертация на соискание ученой степени кандидата философских наук / Иркутский государственный университет. Иркутск, 1999. 210 с.

5. Кремнёв Е.В., Стефановская С.В., Ван Ланьцзюй. Фонетическая стадия эволюции китайской письменности в грамматологической теории И.М. Ошанина // Успехи современной науки и образования. 2016. Т. 2. № 7. С. 118-120.

6. Кремнёва Т.А., Ван Ланьцзюй. Китайский язык. Начальный уровень. Иркутск: МГЛУ ЕАЛИ, 2015. $180 \mathrm{c.}$

7. Кумялова О.В. Сопоставительный анализ сертификационных стандартов алкогольной продукции РФ и КНР // Китай: история и современность: материалы IX Международной научно-практической конференции. Ответственный редактор С. В. Смирнов. 2016. С. 101-105.

8. Макеева С.Б. Особенности социологического осмысления процесса глобализации современного мирового сообщества // Сборник статей по итогам научноисследовательской работы института социально-политических систем Читинского государственного университет за 2009-2010 гг Чита, 2010. С. 15-23.

9. Терехова Н.В. Время синтеза: траектории влияния американской культуры на современное китайское общество // Успехи современного естествознания. 2005. № 2. С. $100-101$.

10. Ядвижина А. Величайшие достижения Китая в науке и технике 2016 ГЭлектронный pecypc]. - 2016. - http: https://laowai.ru/velichajshie-dostizheniya-kitaya-v-nauke-i-texnike2016/

11. Gupta A., Wang H. How China's Government Helps — and Hinders - Innovation / Harvard Business Review 「Electronic resourcel. - 2016. - http: https://hbr.org/2016/11/how-chinasgovernment-helps-and-hinders-innovation

12. Tse E. What Drives China's Innovation? / Forbes [Electronic resource]. - 2016. - http: http://www.forbes.com/sites/tseedward/2016/03/08/what-drives-chinas-innovation2/\#6234334a4071

13. Veresova E., Kuznetsova O. «Soft Power» Concepts in Traditional Chinese Doctrine // Наукасегодня: вызовыирешения: материалымеждународнойнаучнопрактическойконференции. Научный центр «Диспут». 2016. С. 185-186. 